\title{
Welsh Information Literacy Project
}

\author{
Andrew Eynon
}

\begin{abstract}
This report gives an overview of the work to date of the Welsh Information Literacy Project (WILP). WILP is a cross sector project looking to embed information literacy skills across Wales and has been funded by the Welsh Government through CyMAL (Museums, Archives and Libraries, Wales). The report provides specific details of phase three of the project (April 2012-March 2013). The focus of this current phase of the project is the development of information literacy skills amongst public library staff so that these staff can support the development of information literacy skills amongst the whole range of different public library users. In addition, the project is supporting the development of information literacy skills amongst secondary school pupils, by working with school librarians and teachers.
\end{abstract}

\section{Introduction}

The Welsh Information Literacy Project (WILP) was initiated as an outcome of a cross sector gathering of librarians held at Gregynog Hall (University of Wales Conference Centre) in November 2009. The conference led to the creation of the Welsh Information Literacy Steering Group and a successful bid to CyMAL (Museums, Archives, Libraries Wales) brought about WILP.

The first two phases of the project were led by Cardiff University (2009-2011). Since April 2012 the project has been managed by Grŵp Llandrillo Menai (a large FE college situated in North Wales).

\subsection{Aim}

"The Welsh Information Literacy Project aims to promote the understanding and development of information literacy in education, the workplace and the wider community in Wales" (Welsh Information Literacy Project, n.d.).

\section{Author}

Dr Andrew Eynon is Library \& Learning Technology Manager, Grŵp Llandrillo Menai and has worked in further education for over 20 years. He is the Project Manager for WILP and also currently manages a JISC Digital Literacy project on behalf of the 5 North Wales FE colleges.

Email: a.eynon@gllm.ac.uk 


\subsection{Objectives}

In phases one and two (March 2010 - April 2012) the following objectives were set and achieved:

\section{Phase One}

- Produce an overarching statement on information literacy for Wales.

- Report on information literacy provision in each library sector in Wales, identifying case studies of good practice and gaps requiring further enhancement.

- Produce a framework for information literacy in Wales, providing notional levels of information literacy skills and competences for all levels of learners (building on the Scottish framework in the Welsh context).

\section{Phase Two}

- Obtain external approval for the information literacy framework for Wales (working with the Department for Culture Education, Lifelong Learning and Skills, in addition to accrediting bodies).

- Create approved accredited units of learning in information literacy.

- Support advocacy for strategic engagement with information literacy in schools.

- Conduct a benefits analysis of information literacy in the workplace.

- Develop information literacy through the digital inclusion agenda.

\section{Phase Three}

The objectives for the current phase are as follows:

\section{Schools / Education:}

- Promotion and advocacy to highlight the importance and relevance of embedding Information Literacy within the curriculum.

- Support two secondary schools (one in North Wales and one in the South) to run pilot projects on incorporating the Information Literacy framework and/or Agored Information Literacy units. Agored Cymru is the Open College Network for Wales, which accredits formal and informal learning opportunities.

- Establish an information literacy champions' network for school librarians.

\section{Public Libraries:}

- Promotion and advocacy to highlight the importance and relevance of Information Literacy with the wider community (i.e. those outside formal education).

- Support five local authority public library services to run pilot project on developing the Information Literacy skills of their staff. 
- Support two local authority public library services deliver Information Literacy skills to their users.

- Establish an information literacy champions' network for public library staff.

\section{Methodology}

The current phase (Phase 3) has taken the form of three strands; a school strand, a public library strand and an advocacy strand. The project adopted the following approaches for each strand.

\section{Public libraries}

Local authorities from across Wales were invited to nominate staff to become IL champions. The role of the IL Champion was based on the successful Marketing Champions role, which already exists across public, FE and HE library services in Wales. The primary role of the IL Champion is:

- To be the main contact point for all IL issues;

- To attend any IL meetings as appropriate;

- To assist in the delivery of IL training and encourage appropriate staff to partake in such training;

- To communicate and enthuse the latest IL initiatives / campaigns to library staff and users;

- To monitor and feedback on all IL activity where necessary;

- To ensure local IL strategies and plans are consistent with the national strategies;

- To advise the WILP Development Officers about relevant activities of interest/concern;

- To assist in developing yearly IL plans;

- To contribute to IL advocacy.

Thirty-two people from twenty local authorities attended three awareness training sessions held at venues in North, South and Mid-Wales over the summer of 2012 to establish the Champions' network. The resulting virtual network of IL Champions was established with representatives from every public library service in Wales and a regular e-zine has been produced to support the work of the Champions.

Further on-going training events have been held (or are planned) with the pilot local authorities, namely Monmouthshire, Wrexham, Gwynedd, Denbighshire and Merthyr Tydfil. Some of these training sessions have been delivered entirely through the medium of Welsh.

Throughout Phase 3 the project team have continued to develop support and assessment materials for the Agored Cymru IL qualifications in both Welsh and English which can be utilised by any institution across Wales. Much of the IL 
training for public library staff has centred on utilising suitable "hooks" to embed IL in a public library context such as family history, local history, health information, digital literacy and financial literacy.

\section{Schools}

In an effort to raise IL awareness and the Welsh Information Literacy Framework sector, project officers gave presentations at meetings which were attended by head and deputy heads from secondary schools within Conwy County Borough Council and with school library staff from various secondary schools in Wrexham, Flintshire and Denbighshire borough councils via North East Wales School Library Service.

In order to identify secondary schools who were willing to become case studies for the project, individual schools were visited in Anglesey, Conwy, Wrexham, Denbighshire and Cardiff. Meetings took place between head teachers, deputy heads, teachers, library workers and in one case a school governor.

This resulted in two case studies being identified; one at Holyhead High School, Anglesey and the other at Llanishen High School, Cardiff. In the former the school literacy teacher, with the assistance of the school librarian, will lead on embedding the "framework" into curriculum teaching with a number of groups across years 7, 8 and 9 within the classroom situation. In the latter, the school librarian will initiate the piloting of the framework with year 7 groups who visit the library on a regular basis. The two schools are also keen to pilot the Information Literacy Agored units.

Links have also been established with WJEC, the awarding body for the Welsh Baccalaureate qualification, which is offered most school pupils and students in FE at levels 2 and 3 as part of either an academic or vocational programme of study. The WJEC is currently piloting an Information Literacy module as part of these Welsh Baccalaureate qualifications.

In addition, contact has been made with teacher training colleges at Aberystwyth University and Bangor University in order to highlight the importance of information literacy to student teachers before going out on school placements.

The school libraries sector has a significant proportion of lone workers. To support these staff a virtual network has been established using the same platform as the public library IL Champions. It is hoped this schools IL Champions network will grow to rival that of the public libraries.

\section{Advocacy}

There are regular posts by the project on Twitter and we currently have over 1,200 followers (@welsh_info_lit). The project team have disseminated our findings at a variety of events including:

- Danish IL Conference (May 2012);

- CILIP IL Executive Briefing (July 2012);

- CILIP Scotland Autumn gathering (October 2012); 
- JISC Developing Digital Literacies Programme (October 2012);

- Wrexham Libraries Public Libraries staff conference (October 2012);

- Wales Media Literacy Network (December 2012);

- North Wales Libraries Training Group - IL Best Practice event (January 2013).

The project continues to update the WILP webpages which are hosted by the National Library of Wales at http://librarywales.org/index.php?id=7498.

A range of advocacy materials have been produced, which are available on the web site and which highlight the importance of Information Literacy in a number of contexts, such as for employers or schools.

\section{Evaluation}

Evaluation of the current phase of the project will involve the following:

\section{Public libraries}

- To measure staff take-up of the Information literacy training;

- To measure staff take-up and completion of the Agored units;

- To identify suitable "hooks" (i.e. existing public library provision) that could be utilised for informal and formal (incorporating the Agored units) information skills delivery;

- To identify further support materials (including online materials) that are required by staff and/or for use with the public;

- To create case studies of successful IL delivery within the public library sector.

\section{Schools}

- To measure pupil take-up of the Information literacy training;

- To measure pupil take-up and completion of the Agored units;

- To identify further support materials (including online materials) that are required by staff and/or for use with the public;

- To create case studies of successful IL delivery within the school library sector;

- To share assessment materials created as part of the pilot.

\section{Conclusion}

Phase three of the Welsh Information Literacy Project has successfully demonstrated the possibilities for embedding Information Literacy amongst both library staff and their users outside the traditional academic preserve of higher and further education information skills provision. 
Furthermore, the project has helped develop new models of supporting information literacy delivery - through the use of accredited units of learning and through the creation of virtual communities of practice.

We believe the models of delivery we are using are applicable to other parts of the UK and beyond. Moreover, they address the pressing need to improve the information literacy levels of those in work, those seeking employment and those moving on to higher studies.

\section{References}

Welsh Information Literacy Project (n.d.). URL:

http://librarywales.org/en/information-literacy/project/ [accessed 06.05.13].

All the resources mentioned in the report can be obtained from the Welsh

Information Literacy Project Website: http://librarywales.org/index.php?id=7498

\section{Acknowledgement}

The Welsh Information Literacy Project is funded by the Welsh Government via CyMAL (Museums, Archives and Libraries, Wales). My thanks go to the project team at Grŵp Llandrillo Menai: Pat Hebron, Gina Maddison and Siona Murray and to the WILP Steering Group (Chaired by Hywel James, Gwynedd Library Service).

\section{Open access and copyright}

Library and Information Research is an open access journal. A freely available copy of this paper may be downloaded from the journal's website:

http://www.cilipjournals.org.uk/lir

Copyright and associated moral rights in works published in Library and Information Research are retained by the author(s) but this paper may be used freely, with proper attribution, in educational and other non-commercial settings. 